\title{
A Multilingual, Multicultural and Explanatory Music Education Dictionary for South Africa - Using Wiegand's Metalexicography to Establish its Purposes, Functions and Nature"
}

\author{
Maria Smit, Department of Music, \\ University of Stellenbosch, South Africa
}

\begin{abstract}
Wiegand's metalexicography is used to establish the purposes, functions and nature of a multilingual, multicultural, and explanatory music education dictionary for South Africa. Specific types of dictionaries have specific purposes. Special-field dictionaries should fulfil the purpose of conveying information on knowledge in special fields. They should also solve communication conflicts. The genuine purposes of special-field dictionaries, according to Wiegand, are to convey either linguistic information on terms, or encyclopedic information, or both. The needs of users should be taken into account when determining the functions of a dictionary. When the functions of a dictionary containing music terms from South Africa is considered, social factors in South African music education also have to be taken into account. The planned dictionary will have a linguistic and a communicative function. It will also have a cognitive and scientific function, fulfilling an educational need. With regard to the nature of the planned dictionary, it will have to contain elements of different types of dictionaries, such as explanatory dictionaries, translation dictionaries, and leamer's dictionaries. A thematic arrangement will be followed, supplemented by an alphabetical index. Two versions of the dictionary will have to be published, namely, a more scholarly version for specialists, with more types of information, as well as a more popular version for nonspecialists.
\end{abstract}

Keywords: MULTICULTURAL DICTIONARY, MULTILINGUAL DICTIONARY, EXPLANATORY DICTIONARY, SPECIAL-FIELD DICTIONARY, WIEGAND, PURPOSES OF DICTIONARIES, FUNCTIONS OF DICTIONARIES, ENCYCLOPEDIC INFORMATION, LINGUISTIC INFORMATION, DICTIONARY USE, PROTOCOLS, LEARNER'S LEXICOGRAPHY

Opsomming: 'n Veeltalige, multikulturele en verklarende opvoedkundige musiekwoordeboek vir Suid-Afrika. Wiegand se metaleksikografie word gebruik om die doelstellings, funksies en aard van 'n veeltalige, multikulturele en verklarende opvoedkundige

This paper was presented at the Second International Conference of the African Association for Lexicography, held at the University of Natal, Durban, 14-16 July 1997. 
musiekwoordeboek vir Suid-Afrika te bepaal. Spesifieke tipes woordeboeke het spesifieke doelstellings. Vakwoordeboeke behoort die doelstelling te hê om inligting oor kennis in vakgebiede oor te dra. Hulle behoort ook kommunikasiekonflikte op te los. Die ware doelstellings van vakwoordeboeke is, volgens Wiegand, om of linguistiese inligting oor terme oor te dra, of ensiklopediese inligting, of albei. Die behoeftes van die gebruikers moet in ag geneem word wanneer die funksies van ' $n$ woordeboek bepaal word. Wanneer nagedink word oor die funksies van 'n woordeboek wat musiekterme uit Suid-Afrika bevat, moet ook sosiale faktore in die Suid-Afrikaanse musiekopvoeding in ag geneem word. Die beplande woordeboek sal 'n linguistiese en 'n kommunikatiewe funksie hê. Dit sal ook 'n kognitiewe en wetenskaplike funksie hê om in 'n opvoedkundige behoefte te voorsien. Wat die aard van die woordeboek betref, sal dit elemente van verskillende tipes woordeboeke moet bevat, soos verklarende woordeboeke, vertalende woordeboeke en aanleerderswoordeboeke. 'n Tematiese rangskikking sal gevolg word, aangevul deur 'n alfabetiese indeks. Twee weergawes van die woordeboek sal gepubliseer moet word, naamlik 'n meer akademiese weergawe vir spesialiste, met meer tipes inligting, en 'n meer populêre weergawe vir niespesialiste.

Sleutelwoorde: MULTIKULTURELE WOORDEBOEK, VEELTALIGE WOORDEBOEK, VERKLARENDE WOORDEBOEK, VAKWOORDEBOEK, WIEGAND, DOELSTELLINGS VAN WOORDEBOEKE, FUNKSIES VAN WOORDEBOEKE, ENSIKLOPEDIESE INLIGTING, LINGUISTIESE INLIGTING, WOORDEBOEKGEBRUIK, PROTOKOLLE, AANLEERDERSLEKSIKOGRAFIE

In this paper, a brief motivation for the use of H.E. Wiegand's theory of metalexicography in conceptualising an explanatory music dictionary containing terms from all music cultures in South Africa, will be offered.

Wiegand (1984: 559) distinguishes four main research fields within metalexicography. These are: (i) research on the use of dictionaries ("Wörterbuchbenutzungsforschung"), (ii) research into criticism of dictionaries ("kritische Wörterbuchforschung"), (iii) the study of the history of dictionaries ("historische Wörterbuchforschung"), and (iv) the general theory of dictionaries ("systematische Wörterbuchforschung"). Within the general theory of dictionaries the following constituent theories are distinguished by Wiegand (1983: 44): (i) a general section, (ii) an organisational section, (iii) a theory of lexicographical language research, and (iv) a theory of lexicographical language description. Although Wiegand discusses them separately, these components form part of the whole theory, and should all be taken into account in the planning of any dictionary.

\section{The purposes of the planned dictionary}

Those aspects of Wiegand's metalexicography which can help lexicographers establish the most important purposes and functions of dictionaries are mainly drawn from the constituent theories which deal with research into dictionary use, and the general section of the general theory of dictionaries. Wiegand 
(1983a: 314-315) has several practical suggestions for compilers who have to establish the purposes of their dictionaries. For example, one should incorporate the planned dictionary into the "dictionary scene" (Wiegand 1983a: 314) as a whole. The purposes should be formulated to fulfil those needs which can be identified by studying existing dictionaries of the same type. Even such dictionaries which are in their planning or compilation phase should be taken into account. Not only should one look at the collection of lemmata, but also at the contents of the articles of these dictionaries. From this type of research, one can learn a great deal about the advantages and disadvantages of existing and future dictionaries, and try to improve on them. This practice links with the second and third research areas of Wiegand's theory, namely, research into dictionary criticism and into the history of dictionaries.

Specific types of dictionaries have specific purposes. Wiegand (1976: 118) illustrates this assumption by characterising the explanation of word meanings as the "historically constant purpose" of monolingual dictionaries. Bilingual dictionaries, on the other hand, have other purposes. To illustrate this, Zaiping and Wiegand (1987: 229) discuss the purposes of the proposed comprehensive German-Chinese dictionary. They claim that there are scientific, cultural and political reasons why such a dictionary is necessary. ${ }^{1}$ Special-field dictionaries ("Fachwörterbücher") have still other purposes. According to Wiegand (1993: 2 ), one could assume that this type of dictionary should convey information on knowledge in special fields.

Wiegand (1979: 49) also explains that special-field dictionaries are meant to solve communication conflicts which arise particularly when people read texts. Terminologies, he continues (1979: 50), have as main purpose the prevention of communication conflicts with regard to special-field languages.

Wiegand (1988: 743) even suggests that one should further classify the different types of special-field dictionaries according to their genuine purposes ("genuine Zwecke"). This is because some special-field dictionaries tend to give information which is of a more linguistic nature, while others tend to give encyclopedic information, i.e. of an extralinguistic nature. There are even those which equally give both types of information (Wiegand 1988: 747). In accordance with the genuine purposes of a particular special-field dictionary, compilers should decide whether the intended dictionary should convey linguistic information, encyclopedic information, or both. This decision will influence the methods the compilers will follow during the compilation process (Wiegand 1988: 751).

The needs of users and the way in which they will use the planned dictionary should also be taken into account. If one wants to plan the dictionary from a user's perspective, one should incorporate Wiegand's suggestions on typical user needs. In his initial phase of research on dictionary use, Wiegand (1977, 1977a: 57ff) suggests that empirical research should be done in order to determine more exactly what users need from dictionaries. Wiegand (1987: 179) explains that the whole reason for empirical research on dictionary use is to 
ensure that new dictionaries, or revisions of older ones, will be more effective. One can measure the effectiveness of dictionaries according to the occurrence of successful consultations by users. Questionnaires which can reveal information about the different situations of dictionary use, should be drawn up. The questions may vary from those about which people actually own dictionaries and which dictionaries they own, to those about the type of information users need - whether they need to know something about the language (i.e. semantic knowledge) or something about the thing to which the word refers (i.e. encyclopedic knowledge).

This process could lead to the formation of a typology of situations of dictionary use. Wiegand (1977a: 70) distinguishes between (i) situations of passive language use (i.e. when users experience problems when they read texts), (ii) situations of active language use (i.e. when users experience problems when they have to write texts), and (iii) other situations of dictionary use (which are not relevant here).

In a later phase of his research, Wiegand collaborated with Ripfel (Ripfel and Wiegand 1986) to obtain preliminary information for the formulation of a theory of learner's lexicography. They argued (1986: 492) that a draft for a medium-sized, one-volume German learner's dictionary could be designed from such a theory. They started out their investigation by assessing different methods used by researchers up to that stage. After having tried to classify and critically discuss the methods and results ${ }^{2}$, they came to the conclusion that a suitable way of conducting empirical research with regard to dictionary use is the utilisation of protocols. Protocols are utilised when subjects perform certain tasks in which dictionaries are used, at the same time commenting on these tasks by giving information on the type of search questions they had, how they went about to solve their search problems and in which ways the dictionaries used were adequate to solve these problems.

Lexicographers should firstly formulate the purposes of dictionaries in general terms. Secondly they should classify them into groups in such a way that they can derive specific and concrete lexicographical purposes for each dictionary type differentiated by Wiegand's theory of dictionary typology. Such purposes are then set out in the general section of the dictionary plan. This plan is dealt with by Wiegand in his theory about the activities involved when establishing a dictionary basis and processing this basis into a lexicographical file.

As regards the music dictionary planned, at this stage the following can be said about its general purposes: (i) it will fulfil an educational need as there are no other dictionaries of this type yet; (ii) it will serve a scientific purpose, because it will provide subject-field information for research and education in ethnomusicology; and (iii) it will further a cultural aim, because it will enhance communication in the field of music.

Music terms are used in several situations. Firstly, for the practical performance of music, students have to understand the meaning of music terms in 
order to be able to perform the music correctly. This can be characterised as a situation of passive language use. Problem situations which might occur are ones such as word gaps with respect to simplex, compound or derivative gaps, word meaning gaps, word usage gaps, word discrimination gaps, etc.

Secondly, in writing academic dissertations or papers on musical aspects, activities and instruments, students do not only have to understand the meaning of terms (as in passive language use), but they also have to be able to use the terms in their writing (as in active language use). In the process of writing dissertations or papers, students will use literature in which unknown terms occur. They then need the "lexical-semantic knowledge" which is needed in active language use (Wiegand 1977a: 78-80) to "place" a particular term within the relevant semantic "field" or "network." Terms have to be used in a functional and communicative way in this type of language use.

Sometimes problematic situations within African music terminology may also occur because students do not know the morphological structure of the language from which the term comes. The noun denoting a song type such as umtshotsho is derived from $u k u$-thsotsha which is a verb. Users will have to know where to search for these terms, whether at the normal alphabetical place, or at the place where the stem of the word is inserted alphabetically. This problem links with a general problem nonnative speakers of African languages experience when they use dictionaries in African languages.

Research into dictionary use done by Wiegand, as well as that done by others such as Tono, Bensoussan et al. and Mitchell, mainly concern the use of general dictionaries. For special-field lexicography, however, similar tasks to write protocols to describe their use of dictionaries may be given to subjects. From the tasks set by Wiegand (1985) to the subjects in his research project, it can be concluded that there are no dictionaries available yet which give an extensive treatment of the different kinds of African music terminology. ${ }^{4}$ This also implies that it is impossible to compare different types of dictionaries with each other. Lists containing tentative dictionary articles will have to be compiled especially for the purpose of writing protocols, using information in textbooks, journal articles and dissertations. Only then can students be given excerpts from texts in which they may find unknown words which they may want to look up. The texts with which music students will work, will also differ from the one suggested by Wiegand. This is because the texts will not necessarily be translated into another language. It will entail a situation of passive as well as active language use, which means that the students will have to understand what they read and will have to be able to use the information obtained in a paper on the particular topic at hand. Music terminology will not necessarily be translated, because loanwords will be used in, for example, an English text. The meanings and especially the cultural contexts in which these music terms are used, however, are important.

Subjects will have to write down the problems they experienced, and the strategies they used to solve these problems. They could indicate which parts 
of the given "dictionaries" or word lists helped them most in solving problems, in other words, which types of information were most useful.

Only then will researchers be in a position to analyse the answers to these protocols and determine which types of information will be needed in the articles of a music dictionary of the type planned. One could divide the different problem situations into different categories, for example the problems with regard to word gaps, usage gaps, word discrimination gaps, derivation gaps, etc. The possible relationship between the questions of the users and the actual dictionary use can also be determined. Hypotheses could then be formed, which could be tested in later research. Next one could draw up a theoretical framework (or frame, to use Konerding's (1993) approach), as Wiegand suggests, on the basis of which an appropriate dictionary article can be planned. Purposes for this type of dictionary which can finally be formulated, might be to solve search problems with regard to word gaps, usage gaps, word discrimination gaps, derivation gaps, etc.

\section{The functions of the planned dictionary}

When one looks at the purposes of the planned dictionary from the perspective of a social, cultural and political point of view, as Zaiping and Wiegand (1987) do, there are still some other factors to keep in mind. These are, for example, communicative needs, cognitive needs, cultural needs and scientific needs of the potential users. If these needs are considered, one will also be able to determine the functions which such a dictionary will have in the society. For example, some of the social factors in South African music education up to the present need to be taken into consideration. Traditionally, only Western music has been promoted in schools. With the new curricula, this situation has changed. A music dictionary is needed which could fulfil some of the historical, social and cultural needs of the South African society as a whole. African music terms should be recorded in an appropriate way in order to prevent the indigenous cultures from disappearing in a society where all aspects of life have become increasingly westernised.

The main function of the proposed dictionary will consequently have to be to adequately explain the meanings and use of African music terms. In this sense, it will have a linguistic and communicative function. A dictionary which could solve communication conflicts in South African music education is urgently needed. No dictionaries are currently available to students who need to study different kinds of African music. The dictionary should take into account the etic/emic debate in ethnomusicology. Meaning explanations and types of information should be presented in such a way that students from other cultures may understand the semantic and cultural contexts in which expressions are used.

The planned dictionary will have to fulfil a cognitive and scientific function by providing the possibility for research within the field of music, ethno- 
musicology and anthropology.

In addition, a dictionary such as the proposed one should also fulfil an educational need by empowering students to use dictionaries and to interpret the subject matter. One should therefore pay attention to the reference skills of the potential users. These skills, or the absence of such skills, will also have an influence on the eventual access structure of the dictionary. Less educated users will need more guidance than specialists to find the information they want. Wiegand emphasises the usefulness of different access structures. His suggestions in this regard are important for making dictionaries accessible to different users in different ways. ${ }^{5}$ This aspect links with the function of empowerment that a dictionary of the proposed type will have. Various innova. tive access structures will therefore have to be devised for users with different levels of reference skills and different search priorities. Especially in a computerised version of such a dictionary, one should explore the different possibilities of access structures when multi-media or hypertext is used.

\section{The nature of the planned dictionary}

The purposes of a dictionary such as the planned music dictionary have a definite influence on the types of information which will have to be included. For various reasons, it is foreseen that the planned dictionary will have to be a typological hybrid. It will have to possess characteristics from different dictionary types in order to fulfil the needs of the potential users. It should not only be a special-field dictionary in the traditional sense. For example, it will have to incorporate elements of explanatory dictionaries, because encyclopedic as well as meaning explanations will have to be included. It will in addition have to be translatory, because terms from African musical cultures might have translation equivalents in other languages. Elements of learner's lexicography will also have to be incorporated, because students have to "acquire" a "special-field language", namely musical terms from different indigenous cultures. Furthermore, it is believed that such a dictionary would do well to follow a thematic arrangement instead of an alphabetical one, because concepts could then be studied within their natural contexts.

In terms of Wiegand's metalexicography, it is necessary to distinguish between different types of dictionary use and between different types of users. Firstly, students in secondary education, undergraduates as well as educated nonspecialists who want to acquire knowledge about the music cultures of South Africa, will be one of the target groups. A music dictionary should be able to provide suitable information which these students could use in their musicological and anthropological studies. Secondly, the dictionary will also have to be published in a more scholarly version for the sake of specialists. This version of the dictionary will have to supply enough information to enhance and encourage scientific research within ethnomusicology. References should be made to relevant literature to make it possible for researchers to obtain additional information when needed. It should, therefore, be possible to distinguish 
between a more popular version of the dictionary for the purposes of nonspecialists and a more academic version for the purposes of specialists. In a computerised version of the planned dictionary, the use of video clippings, sound recordings and "lexicographical narration", as Wiegand (1977: 107) calls it, have interesting possibilities when they can be used within the frames of the dictionary articles at the specific places where they are needed.

\section{Summary}

Wiegand's theoretical framework is the only one which deals extensively with all aspects of dictionary planning and making. It is clear that, for the purposes of the planned music dictionary, Wiegand's framework is certainly useful. This does not mean that one can use it without any adaptations. The theory should be used as a basis for determining what is needed to compile a customised dictionary which will fulfil the needs of the potential users. Wiegand has for example not dealt with all aspects to the same extent. Certain aspects, such as communication in special fields, user situations in the case of special-field dictionaries, the latest developments in computerisation, aspects of corpus lexicography, etc., will have to be worked out in more detail before a music dictionary of the kind proposed here can be compiled.

It is, however, of crucial importance that aspiring lexicographers pass through all the phases of Wiegand's theory in order to lay a sound theoretical basis for the planning and compilation of their dictionaries. In the case of the proposed music dictionary which will include terms from African and possibly also Indian and Western music, this is also valid. No final decisions or conclusions can be made or drawn with regard to any of the mentioned aspects before one has not completed all the steps in Wiegand's theoretical framework.

\section{Notes}

1. For example, such a dictionary would enhance communication between Germans and Chinese who share many scientific and technical projects. There are a few existing dictionarjes, but they do not contain recent lexical items. In determining the purposes of this GermanChinese dictionary, the compilers took into consideration the needs of the users. In the first place the dictionary is meant for Chinese users who know German well and need the dictionary in university research and lectures. In the second place, German users may also find it a useful dictionary. The dictionary also has several functions: Firstly, it fulfils the needs of Chinese speakers who have to translate from German to Chinese ("Herübersetzen.") Secondly, a Chinese speaker who wants to produce German texts ("Hinproduktion") may also find the dictionary useful. For German users, it may be helpful in situations of producing Chinese texts in the first place, and in the second place it helps them with translating from Chinese to German.

Cf. also Kromann et al. (1991: 2712-2713) who list a few purposes of bilingual dictionaries. For example, they claim that bilingual dictionaries can serve as "important tools in language leaming". Furthermore, they are "useful aids to travel abroad and communication in foreign 
languages, necessary tools in the commercial world and public administration, and indispensable for secretaries dealing with foreign-language correspondence, translators and interpreters." They (1991: 2712) also refer to "specialized translation dictionaries", which they consider important in international specialised communication between companies, public authorities and international organisations. Then there are also "translation dictionaries of the scholarly historical-philological type, which serve research in the humanities and the interpretation of older texts and cultures", for example, translation dictionaries with Biblical Hebrew, Classical Greek and Latin as the source languages.

2. The research by Ard (1982), Hatherall (1984), Bensoussan et al. (1984), Mitchell (1983), Tono (1984) and Wiegand (1985) was taken into account here.

3. Wiegand (1983: 58 , note 35) states that one can list the purposes of a dictionary in the dictionary introduction by characterising in an organised way the situations of use for the dictionary type at hand. One could regard situations of dictionary use as a triangle of (i) dictionary user, (ii) the question which the user directs towards the dictionary, and (iii) and the dictionary itself.

4. One exception is within the field of musical instruments, where the New Grove Dictionary of Musical Instruments (Sadie:1980) includes the terms for African musical instruments. Other publications which also deal with musical instruments are e.g. Sachs (1962), Brincard (1989), Wegner (1984) and Norborg (1987). For other types of terms such as those designating musical activities and musical forms, there are no lexicographical publications in which these terms can be looked up;

5. Cf. also McArthur (1986: 178-179), who stresses the importance of working from a menu (as on the computer), via "an alphabetic or thematic-and-numerical indexing system", and operating "according to our own system of priority". He (1986: 183) believes that this helps in "democratizing" the handling of the information.

\section{References}

Ard, J. 1982. The Use of Bilingual Dictionaries by ESL Students while Writing. ITL Review of Applied Linguistics 55: 1-27.

Bensoussan, M. et al. 1984. The Effect of Dictionary Use on EFL Text Performance Compared with Student and Teacher Attitudes and Expectations. Reading in a Foreign Language 2: 262-276.

Brincard, M-T. 1989. Sounding Forms: African Musical Instruments. New York: The American Federation of Arts.

Hatherall, G. 1984. Studying Dictionary Use: Some Findings and Proposals. Hartmann, R.R.K. (Ed.). 1984. LEXeter '83 Proceedings. Papers from the International Conference on Lexicography at Exeter, 9-12 September 1983: 183-189. Tübingen: Max Niemeyer.

Konerding, H-P. 1993. Frames und lexikalisches Bedeutungswissen. Untersuchungen zur linguistischen Grundlegung einer Frametheorie und zu ihrer Anwendung in der Lexikographie. Reihe Germanistische Linguistik 142. Tübingen: $\mathrm{M}$ lax Niemeyer.

Kromann, H-P. et al. 1991. Principles of Bilingual Lexicography. Hausmann, FJ. et al. (Ed.). 1991. Wörterbücher. Ein internationales Handbuch zur Lexikographie / Dictionaries. An International Encyclopedia of Lexicography / Dictionnaires. Encyclopédie internationale de lexicographie: 27112728. Handbücher zur Sprach- und Kommunikationswissenschaft 5.2. Berlin: De Gruyter. 
McArthur, T. 1986. Worlds of Reference. Cambridge: Cambridge University Press.

Mitchell, E. 1983. Search-do Reading: Difficulties in Using a Dictionary. Formative Assessment of Reading, Working Paper 21. Aberdeen: College of Education.

Norborg, A. 1987. A Handbook of Musical and Other Sound-Producing Instruments from Namibia and Botswana. Musikmuseetsskrifter 13. Stockholm: [A. Norborg].

Ripfel, M. and H.E. Wiegand. 1986. Wörterbuchbenutzungsforschung. Ein kritischer Bericht. Germanistische Linguistik: Studien zur neuhochdeutschen Lexikographie 6: 490-520.

Sachs, C. 1962. Real-Lexikon der Musikinstrumente. Hildesheim: Olms.

Sadie, S. (Ed.). 1980. The New Grove Dictionary of Music and Musicians. London: MacMillan.

Tono, Y. 1984. On the Dictionary User's Reference Skills. Unpublished B.Ed. thesis. Tokyo Gakugei University.

Wegner, U. 1984. Afrikanische Saiteninstrumente. Berlin: Museum für Völkerkunde.

Wiegand, H.E. 1976. Synonymie und ihre Bedeutung in der einsprachigen Lexikographie. Moser, H. (Ed.). 1976. Probleme der Lexikologie und Lexikographie: Jahrbuch 1975 des Instituts für deutsche Sprache: 118-180. Düsseldorf: Pädagogischer Verlag Schwann.

Wiegand, H.E. 1977. Einige grundlegende semantisch-pragmatische Aspekte von Wörterbucheinträgen. Hyldgaard-Jensen, K. (Ed.). 1977. Kopenhagener Beiträge zur germanistischen Linguistik: 59-149. Copenhagen: Universitetsforlaget.

Wiegand, H.E. 1977a. Nachdenken über Wörterbücher: Aktuelle Probleme. Drosdowki, G., H. Henne and H.E. Wiegand. 1977. Nachdenken über Wörterbücher: 51-102. Mannheim: Bibliographisches Institut.

Wiegand, H.E. 1979. Kommunikationskonflikte und Fachsprachengebrauch. Mentrup, W. (Ed.). 1979. Fachsprachen und Gemeinsprache: Jahrbuch 1978 des Instituts für deutsche Sprache: 25-58. Düsseldorf: Pädagogischer Verlag Schwann.

Wiegand, H.E. 1983. Überlegungen zu einer Theorie der lexikographischen Sprachbeschreibung. Germanistische Linguistik 5-6: 35-72.

Wiegand, H.E. 1983a. Zur Geschichte des deutschen Wörterbuchs von Hermann Paul. Zeitschrift für germanistischen Linguistik 11: 301-320.

Wiegand, H.E. 1984. Prinzipien und Methoden historischer Lexikographie. Besch, W. et al. (Ed.). 1984. Sprachgeschichte. Ein Handbuch zur Geschichte der deutschen Sprache und ihrer Erforschung: 557-620. Handbücher zur Sprach- und Kommunikationswissenschaft 2.1. Berlin: De Gruyter.

Wiegand, H.E. 1985. Fragen zur Grammatik in Wörterbuchbenutzungsprotokollen. Ein Beitrag zur empirischen Erforschung der Benutzung einsprachiger Wörterbücher. Bergenholtz, $\mathrm{H}$. and J. Mugdan. 1985. Lexikographie und Grammatik. Akten des Essener Kolloquiums zur Grammatik im Wörterbuch, 28-30.6.1984: 20-98. Lexicographica Series Maior 3. Tübingen: Max Niemeyer.

Wiegand, H.E. 1987. Zur handlungstheoretischen Grundlegung der Wörterbuchbenutzungsforschung. Lexicographica 3: 178-227.

Wiegand, H.E. 1988. Was eigentlich ist Fachlexikographie? Munske, H.H. et al. (Ed.). 1988. Deutsche Wortschatz: Lexikologische Studien: 729-790. Berlin: De Gruyter.

Wiegand, H.E. 1993. Zur Unterscheidung von semantischen und enzyklopädischen Daten in Fachwörterbüchern. Unpublished paper.

Zaiping, P. and H.E. Wiegand. 1987. Konzeption für das grosse deutsch-chinesische Wörterbuch (zweiter Entwurf). Lexicographica 3: 228-241. 